\title{
DRYING KINETICS OF INDONESIAN PEAT
}

\author{
Pither Palamba ${ }^{1}$, Mohamad Lutfi Ramadhan ${ }^{1}$, Agus Sunjarianto Pamitran ${ }^{1}$, Gatot Prayogo ${ }^{1}$, \\ Engkos Achmad Kosasih ${ }^{1}$, Yulianto Sulistyo Nugroho ${ }^{1^{*}}$ \\ ${ }^{1}$ Department of Mechanical Engineering, Faculty of Engineering, Universitas Indonesia, Kampus UI \\ Depok, Depok 16424, Indonesia
}

(Received: October 2017 / Revised: June 2018 / Accepted: July 2018)

\begin{abstract}
Indonesia has the largest peatland area in the tropical region, situated mainly in Sumatra, Kalimantan and Papua. Peat is an organic substance which is highly combustible in dry conditions; dried peat can burn easily and spread vertically and laterally along peat layers. In Indonesia, peat fires have often occurred in recent decades. Besides being influenced by the amount of organic content, smoldering peat fires are also effected by the drying rate, pyrolysis, and heterogeneous oxidation on the peat surfaces. In contrast to flaming combustion, which have been widely studied, smoldering peat fires remain little understood. To date, the major peat fire-related publications concern the pyrolysis and combustion stages. The contribution of the drying kinetics of peat in the peat fire phenomenon is important, as this could provide complete understanding of the peat fire process. The objective of this paper is to make an isothermal drying kinetics analysis of peat. Peat samples were taken from various locations in Indonesia with the largest peat distribution, namely South Sumatra, Central Kalimantan and Papua. An isothermal test was conducted using a Shimadzu MOC63u Moisture Balance. At certain interval times, the weight of the specimen was measured, until it reached a constant weight of less than a $0.05 \%$ change in moisture content. Isothermal analysis was conducted for each peat sample at temperatures of $60,70,80,90,100$, and $110^{\circ} \mathrm{C}$. The results show that the activation energies from the isothermal measurement test were 24.97, 25.08, and $30.11 \mathrm{~kJ} / \mathrm{mole}$ for Papuan, South Sumatran and Central Kalimantan peat, respectively.
\end{abstract}

Keywords: Activation energy; Drying kinetics; Evaporation rate; Moisture content; Peat

\section{INTRODUCTION}

Peatlands are ecosystems which play a very important role in maintaining the balance of carbon, water and climate. Indonesia is the tropical country with the largest peatland area, of approximately 20.6 million ha, which is mainly distributed in the three large islands of Sumatra (35\%), Kalimantan (32\%) and Papua (30\%) (Ritung et al., 2012). Peatlands store carbon (C) in large quantities and have high water retention, which acts as a hydrological buffer for the surrounding area, even during the El Niño and La Niña phenomena (Piman et al., 2016). Usually, living wood has an affinity for moisture and holds a relatively high moisture content internally, due to soil moisture (Hossain et al., 2017). Equilibrium moisture content of the peat layer becomes difficult to maintain if forests have been cleared and converted into plantations or other uses, because these processes are usually irreversible.

In the long dry season, forests and peatlands may undergo substantial evapotranspiration, which

*Corresponding author's email: yulianto@eng.ui.ac.id, Tel: +62-21-7270032, Fax: +62-21-7270033

Permalink/DOI: https://doi.org/10.14716/ijtech.v9i5.805 
leads to droughts, subsequently resulting in a decrease in moisture content. If it has become dry, the peat that was originally hydrophilic becomes hydrophobic (water-repellent, not easily penetrated by water) (Valat et al., 1991; Murtilaksono et al., 2016; Perdana et al., 2018). In such conditions, peat is highly flammable, and when burning smoldering combustion in the peat, biomass and low-rank coal piles can continue for a long time and be difficult to extinguish (Saleh et al., 2017). Peat fire events originate from peatland conditions that have become dry, with the highest moisture content that can burn is approximately $250 \%$ (dry base) (Rein et al., 2008) or $150 \%$ (Prat-Guitart et al., 2016). The drying process takes place in two stages, namely heating and drying, and occurs through the changes in temperature, relative humidity and air flow (Kosasih et al., 2016). The drying stage begin with the release of free water from the large pores of the soil. Further heating causes the strength of the capillary contraction to increase, so that the capillary water out of the soil particles at a constant drying rate. Further dehydration results in the molecular structure of the soil becoming brittle, which will be followed by the release of hygroscopic water in the falling rate period. Chemically bound water, which is not removed in the drying process, possesses the highest binding energy (Grishin et al., 2003).

With regard to the drying process, the drying kinetics of peat need to be studied to understand the drying rate, moisture content and activation energy. One study on the drying kinetics of peat by Filkov (Filkov et al., 2012) using Thermogravimetry Analysis (TGA) for micro scale and KAS (Kissinger - Akahira - Sunose) isoconventional method based on the modelling of the mass loss with Arrhenius's Law. From those methods, the activation energy and the thermokinetic constants for the drying process of three boreal peat from two regions (Edinburgh, Scotland and Tomsk, Russia) could be obtained. (Nugroho, 2002) used tropical peat material taken from Kalimantan, Indonesia, using the differential form of the Arrhenius equation method. He found that the activation energy of the peat sample was lower than other materials such as palm fibre, and wood, which indicated that it was easier for peat to react with oxygen. Some studies relating to the drying of peat include experimental study of its thermophysical and thermokinetic characteristics. (Grishin et al., 2006) found values of activation energy of $47.376 \mathrm{~kJ} / \mathrm{mole}$, and, in an investigation of the thermal analysis and decomposition kinetics of Chinese forest peat, Chen et al. (2011) found a value of activation energy of $68.510 \mathrm{~kJ} / \mathrm{mole}$. Each type of material has a specific drying curve, which is dependent on the physical and chemical characteristics of the substance. This research aims to study the isothermal drying kinetics of tropical peat taken from the Papua, South Sumatera, and Central Kalimantan provinces of Indonesia, to determine the moisture content, drying rate and activation energy, as the initial stages of the overall process of smoldering peat fires. The experimental results are expected to provide sufficient understanding of integrating fire risk consideration and management, especially with regard to peatland fires (Nugroho, 2017).

\section{MATERIALS AND METHODS}

The sample in this research is part of those used in previous studies (Palamba et al., 2017; Ramadhan et al., 2017), which were collected from the Kayu Agung Sub-district of Ogan Komering Ilir Regency (South Sumatera Province) and Bagaiserwar Sub-district of Sarmi Regency (Papua Province), supplemented with samples extracted from the Pulang Pisau district of Central Kalimantan province, which is indicated by the coordinates on the map shown in Figure 1. Since the average water table in all three locations was approximately $40 \mathrm{~cm}$, sampling used the undisturbed method at 50-110 cm deep, using a 6 inch diameter and $60 \mathrm{~cm}$ length PVC pipe. Both ends of the pipe containing the sample were sealed with epoxy (resin hardener) to retain the sample characteristics and to prevent contamination from microbes activity and other chemical reactions, until the tests were conducted. The peat samples taken from the three locations were analysed and classified into hemic-sapric peat. 


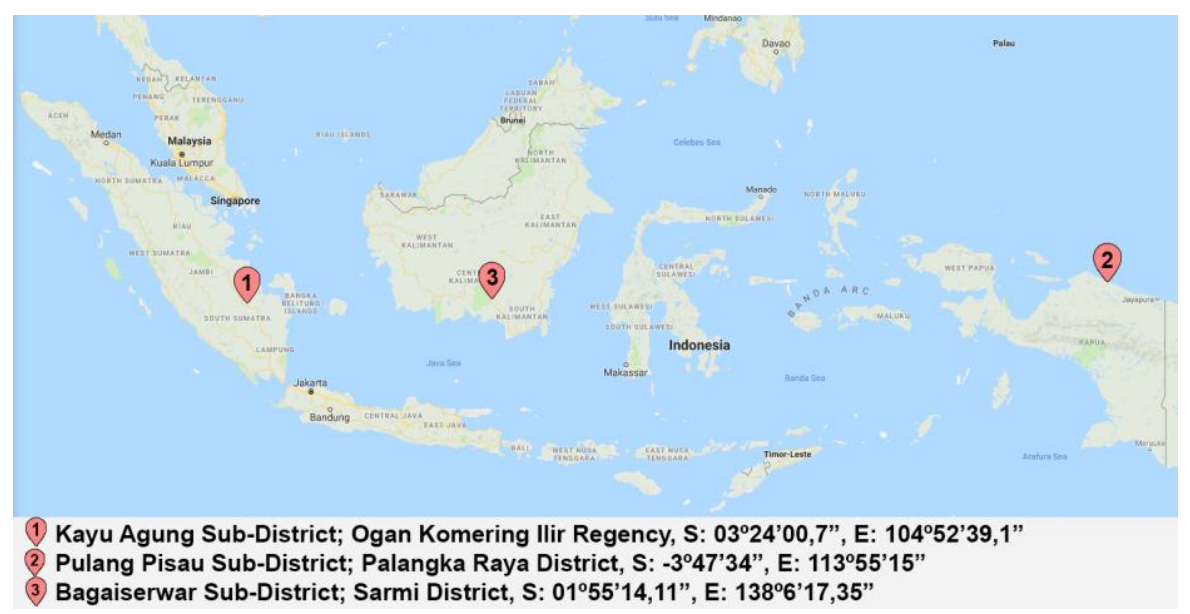

Figure 1 Locations of peat sampling

The tests were carried out using a calibrated moisture analyser (MOC63u Shimadzu Moistture Analyser), equipped with a high output halogen heater capable of rapid heating, with a power of $400 \mathrm{~W}$ and temperature range of $50-200^{\circ} \mathrm{C}$. It uses the mass difference method to detect the moisture content of the sample. The instrument also consists of a weighing mechanism with an accuracy of $0.001 \mathrm{mg}$. The instrument was programmed until the specimen reached a constant weight, with an accuracy of $\pm 0.05 \%$ moisture content. It was connected to a computer to record the mass and moisture content evolution during the drying process. In contrast to the conventional moisture measurement that is generally associated with environmental conditions, this moisture analyser operates in a closed state, so it is not affected by ambient humidity and other environmental conditions.

Measurements were made in isothermal drying conditions, at $60,70,80,90,100$, and $110^{\circ} \mathrm{C}$, with samples weighing 2 grams. The analysis of the relationship between the drying temperature and the reaction rate constant was derived from the Arrhenius equation in order to obtain the activation energy, i.e. the minimum energy required for a chemical reaction to take place. In this case, "activation" means that a chemical reaction requires additional energy (activation energy is always positive) to take place, both endothermic and exothermic reactions. According to the Arrhenius equation, the reaction rate constant depends on the temperature and activation energy, as follows:

$$
k=A e^{-E a /(R T)}
$$

where $k$ is the rate constant $\left(\mathrm{s}^{-1}\right), T$ is the absolute temperature $(\mathrm{K}), A$ is the pre-exponential factor, $E a$ is the activation energy for the reaction $(\mathrm{kJ} / \mathrm{mol}), R$ is the universal gas constant $(8.314 \mathrm{~J} / \mathrm{K} \cdot \mathrm{mol})$.

Taking the natural logarithm of the Arrhenius equation yields:

$$
\ln (k)=\ln (A)-\frac{E a}{R} \frac{1}{T}
$$

and rearranging yields:

$$
\ln (k)=\frac{-E a}{R}\left(\frac{1}{T}\right)+\ln (A)
$$


Equation 3 has the form of a straight line:

$$
y=m x+c
$$

Therefore, a plot of $\ln k$ versus $T^{-1}$ of a reaction rate constant that obeys the Arrhenius equation results in a straight line, on which the gradient and intercept give a value of activation energy and pre-exponential factor. Determining the amount of activation energy is made by graphical methods derived from a formula based on the Arrhenius equation. The formula used for the first-order reaction is as follows:

$$
-\frac{d m}{d t}=k m
$$

where $m$ is the mass of a sample at time $t$, and $k$ is the reaction rate constant. Equation 5 above can be written as:

$$
-\frac{d\left(m-m_{f}\right)}{d_{t}}=k\left(m-m_{f}\right)
$$

where $m_{f}$ is the mass of the sample at the end of the process. By arranging and integrating Equation 6, we obtain:

$$
-\ln \left(\frac{m-m_{f}}{m_{0}-m_{f}}\right)=k t
$$

where $m_{0}$ is the initial mass of the peat sample. Based on the mass evolution data at each heating temperature, the relationship between $-\ln \left(\frac{m-m_{f}}{m_{0}-m_{f}}\right)$ and $t$ (time) is a straight line, with the slope of the line representing the value of $k$ (reaction rate constant), while the Arrhenius equation states that:

$$
k=k_{0} \cdot e^{\left(\frac{-E}{R T}\right)}
$$

when both sides are set to the natural logarithm, Equation 8 can therefore be expressed as:

$$
\ln k=\ln k_{0}-\frac{E}{R T}
$$

A curve describing the relationship between $\ln k$ and 1/T will yield a straight line with a slope equal to $E / R$. By describing these relationships to all the appropriate temperatures, the Arrhenius plot was then used to determine the values of the activation energies and frequency factors.

\section{RESULTS AND DISCUSSION}

Figure 2 shows the mass evolution during evaporation at various temperatures. Based on Figure 2 , the characteristics of isothermal evaporation only depend on the heating temperature. With heating at a low temperature, the curve will be much shallower than at a higher temperature. Thus, the time needed to reach dry conditions (characterized by the absence of further loss up to $0.05 \%$ moisture) at low heating temperatures will be longer. Similarly, as shown in Figure 4, 
the average evaporation rate tends to increase with an increasing heating temperature. The moisture content measurements made in line with the temperature variations can be seen in Table 1.

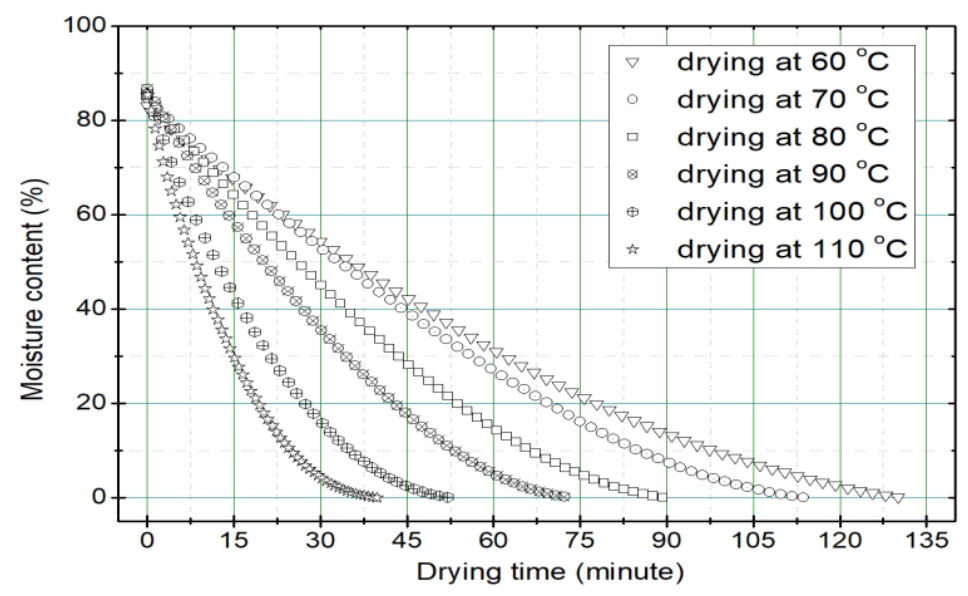

Figure 2 Drying curve of Papuan peat

The drying curve illustrated in Figure 2 shows that the Moisture Content (MC) changes over time. As can be seen by the curve, the drying process follows three stages, which are preheating period, a constant-rate period and a falling rate period. In the preheating period, the heat provided will only be used to heat the sample until it reaches the drying temperature and the drying rate is almost equal to zero. In the next period, the heat will be used to evaporate the mechanically bonded water content of the sample surface at a constant rate. In the falling rate drying period, heating will result in the physico-chemically bound water seeping out of the soil particles with the decreasing drying rate. The periods of the drying process are illustrated in Figure 3 for a drying curve at a constant temperature of $100^{\circ} \mathrm{C}$.

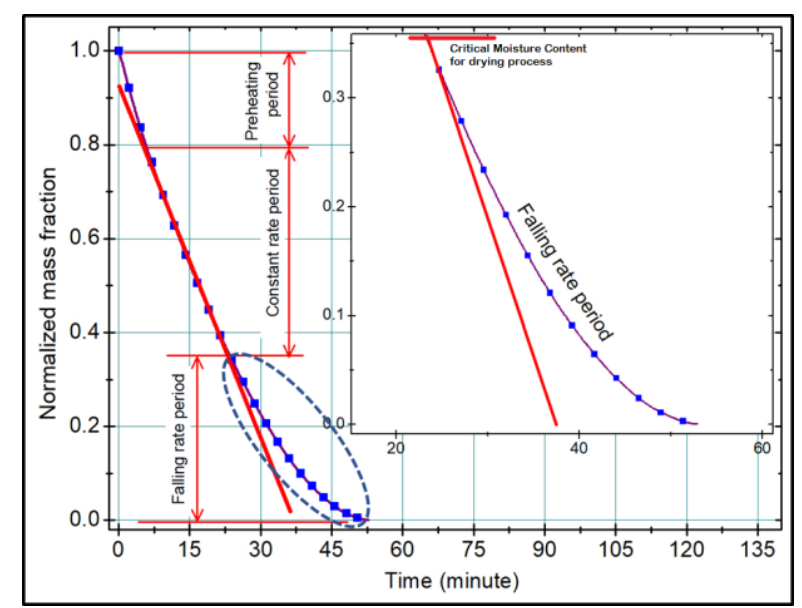

Figure 3 Illustration of the falling rate period in the drying process

Determination and calculation of the evaporation rate $(k)$ and activation energy $(E a)$ were based on the data of the falling period. From the drying curve (Figure 2), the falling rate period determined to obtain the evaporation rate, as shown in Figure 4. 


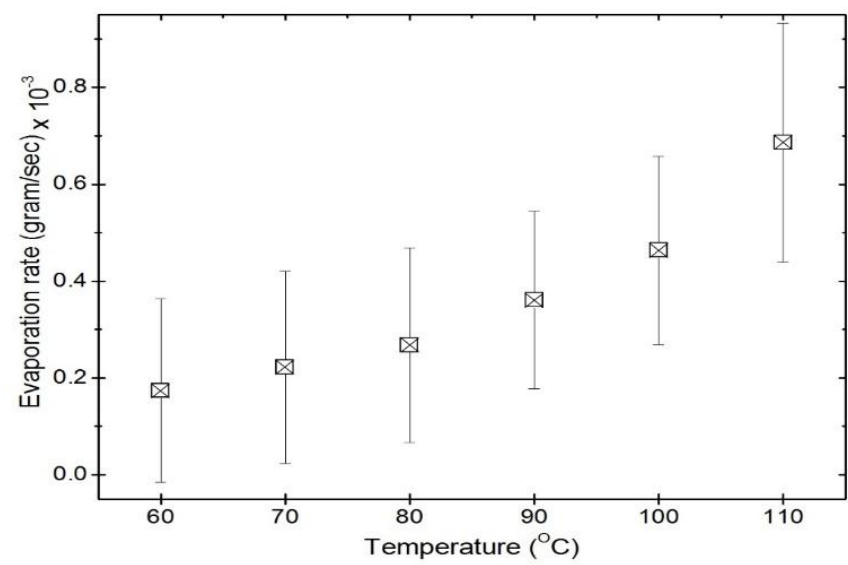

Figure 4 Average evaporation rate in the falling period with standard deviation of the Papuan peat drying

Applying Equation 7 and plotting the relationship between mass evolution and $t$, we obtained a polynomial curve for isothermal drying at each drying temperature. As an example, the polynomial curve for drying at $100^{\circ} \mathrm{C}$ is shown in Figure 5 .

Based on the equation of the straight line (Figure 5) it can be seen the reaction rate constants $(k)$ at drying temperatures of $60^{\circ} \mathrm{C}, 70^{\circ} \mathrm{C}, 80^{\circ} \mathrm{C}, 90^{\circ} \mathrm{C}, 100^{\circ} \mathrm{C}$, and $110^{\circ} \mathrm{C}$ are $0.0006113,0.000685$, $0.000891,0.001124,0.001401$, and $0.001726 \mathrm{~s}^{-1}$, respectively. By taking the logarithm of these constants and plotting them against 1/T, the linear fit equation shown in Figure 6 was obtained.

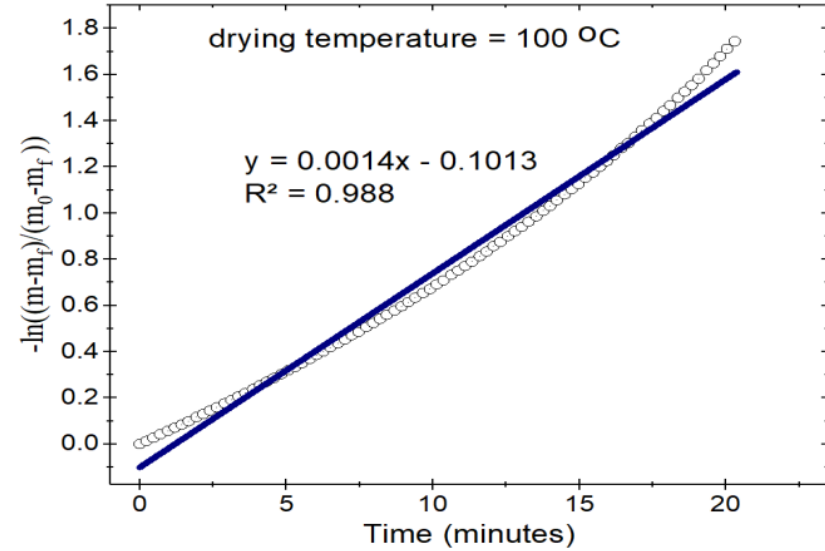

Figure 5 Natural logarithm of $\left(m-m_{f}\right) /\left(m_{0}-m_{f}\right)$ versus the time curves with a first order polynomial fit for isothermal evaporation at a drying temperature $100^{\circ} \mathrm{C}$ for Papuan peat

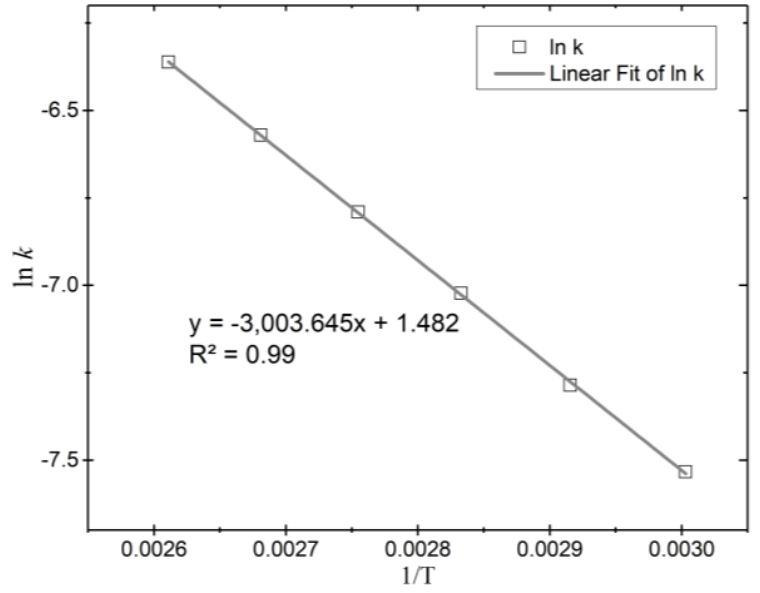

Figure 6 Trendline of $\ln k$ versus $1 / \mathrm{T}$ at various temperatures for Papuan peat drying

For the three types of peat sample used in this test, the trendline of $\ln k$ versus $1 / \mathrm{T}$ at various temperatures and the value of the activation energy results obtained are shown in Table 1.

Table 1 Summary of the results of the three types of peat drying

\begin{tabular}{lccc}
\hline \multicolumn{1}{c}{ Sample } & MC $(\%)$, wet base & Trendline equation, $\mathrm{y}$ & $\mathrm{Ea}(\mathrm{kJ} / \mathrm{mole})$ \\
\hline Papuan peat & $85.33 \pm 1.26$ & $\mathrm{y}=-3,003.64 \mathrm{x}+1.482$ & 24.97 \\
South Sumatran peat & $87.01 \pm 1.92$ & $\mathrm{y}=-3,016.63 \mathrm{x}+0.947$ & 25.08 \\
Central Kalimantan peat & $85.79 \pm 2.06$ & $\mathrm{y}=-3,622.20 \mathrm{x}+2.63$ & 30.11 \\
\hline
\end{tabular}


The straight-line equations shown in

Table 1 are correlated with the Arrhenius equation (Equation 2). Thus, it can be calculated that the activation energy of the sample drying amounted to $24.97,25.08$, and $30.11 \mathrm{~kJ} / \mathrm{mol}$ for the Papuan, South Sumatran and Central Kalimantan peat, respectively.

These values are lower than those obtained in the tests performed by Filkov et al. (2012) on boreal peat, which showed an activation energy of $36.1-42.26 \mathrm{~kJ} / \mathrm{mol}$, as well as those by (Nugroho, 2002), who found a value of $44 \mathrm{~kJ} / \mathrm{mol}$ for Kalimantan peat; Grishin (Grishin et al., 2003) whose obtained value was $47 \mathrm{~kJ} / \mathrm{mol}$; and Chen (Chen et al., 2011), who found $E_{a}=68.5$ $\mathrm{kJ} / \mathrm{mol}$ for Chinese peat. Likewise, the activation energy for soils from the Long Term Bare Fallow (LTBF) experiments ranged from 49 to $79 \mathrm{~kJ} / \mathrm{mol}$ (Lefèvre et al., 2014), and in a study on peat respiration at low temperatures considering $\mathrm{O}_{2}$ uptake (Chapman et al., 1998), the activation energy varied between 58 and $148 \mathrm{~kJ} / \mathrm{mol}$.

The differences in the results obtained compared to the previous studies are due to differences in the physical and chemical properties of peat, such as moisture content, bulk density, and the degree of decomposition. Determination of drying isothermal activation energy is also strongly influenced by the accuracy of the equipment and the variance in temperature of the drying process, which will affect the slope of the trendline of the plots (because in this method, the value of activation energy depends on the slope of the line), as well as determining the falling rate period as the basis for the calculation of the activation energy.

\section{CONCLUSION}

In general, an increase in drying temperature will cause the reaction rate to increase. Temperature is a measure of the average kinetic energy of a molecule; raising the temperature will increase the existing kinetic energy and break the molecular bonds when collisions occur. The minimum kinetic energy possessed by a molecule must be equal to, or greater than, the activation energy for the reaction to take place. In other words, to initiate a chemical reaction, intermolecular collisions must have a minimum total kinetic energy equal to, or greater than, the activation energy $\left(E_{a}\right)$. As well as peat drying process, the minimum amount of activation energy is required, so that the evaporation process can take place and the peat becomes dry. The activation energy for the drying of Papuan, South Sumatran and Central Kalimantan peat obtained amounts of 24.97, 25.08, and $30.11 \mathrm{~kJ} / \mathrm{mol}$, respectively. In this study, the factors which affected the drying process were temperature and moisture content. The drying temperature applied determined the reaction rate.

\section{ACKNOWLEDGEMENT}

The authors would like to thank the financial support provided by Ministry of Research, Technology and Higher Education of the Republic of Indonesia through Penelitian Terapan Unggulan Perguruan Tinggi (PTUPT) 2018 funding scheme under Grant No. 514/UN2.R3.1/HKP05.00/2018 managed by the Directorate for Research and Public Services (DRPM) Universitas Indonesia.

\section{REFERENCES}

Chapman, S.J., Thurlow, M., 1998. Peat Respiration at Low Temperatures. Soil Biology and Biochemistry, Volume 30(8-9), pp. 1013-1021

Chen, H., Zhao, W., Liu, N., 2011. Thermal Analysis and Decomposition Kinetics of Chinese Forest Peat under Nitrogen and Air Atmospheres. Energy \& Fuels, Volume 25(2), pp. 797 803 
Filkov, A.I., Kuzin, A.Y., Sharypov, O.V., Leroy-Cancellieri, V., Cancellieri, D., Leoni, E., Simeoni, A., Rein, G., 2012. Comparative Study to Evaluate the Drying Kinetics of Boreal Peats from Micro to Macro Scales. Energy \& Fuels, Volume 26(1), pp. 349-356

Grishin, A., Golovanov, A., Sukov, Y.V., 2006. Experimental Determination of Thermophysical, Thermokinetic, and Filtration Characteristics of Peat. Journal of Engineering Physics and Thermophysics, Volume 79(3), pp. 557-562

Grishin, A., Kuzin, A.Y., Alekseenko, E., 2003. Determination of Kinetic Characteristics of the Process of Drying of Forest Combustibles. Journal of Engineering Physics and Thermophysics, Volume 76(5), pp. 1160-1165

Hossain, N., Jalil, R., Mahlia, T., Zaini, J., 2017. Calorific Value Analysis of Azadirachta Excelsa and Endospermum Malaccense as Potential Solid Fuels Feedstock. International Journal of Technology, Volume 8(4), pp. 634-643

Kosasih, E.A., Ruhyat, N., 2016. Combination of Electric Air Heater and Refrigeration System to Reduce Energy Consumption: A Simulation of Thermodynamic System. International Journal of Technology, Volume 7(2), pp. 288-295

Lefèvre, R., Barré, P., Moyano, F.E., Christensen, B.T., Bardoux, G., Eglin, T., Girardin, C., Houot, S., Kätterer, T., Oort, F., Chenu, C., 2014. Higher Temperature Sensitivity for Stable Than for Labile Soil Organic Carbon-evidence from Incubations of Long-term Bare Fallow Soils. Global Change Biology, Volume 20(2), pp. 633-640

Murtilaksono, K., Sabiham, S., Sutandi, A., Sutarta, E.S., 2016. Hydrophobicity of Tropical Peat Soil from an Oil Palm Plantation in North Sumatra. Journal of Agronomy, Volume 15(3), pp. 114-121

Nugroho, Y.S., 2002. Sifat Self-Ignition pada Gambut, Sabut Kelapa Sawit dan Kayu (SelfIgnition Properties of Peat, Oil Palm and Wood Coir). Makara Journal of Technology, Volume 6, pp. 123-131

Nugroho, Y.S., 2017. Integrating Wildland and Urban Fire Risks in Local Development Strategies in Indonesia. Fire Science and Technology 2015, pp. 31-43

Palamba, P., Ramadhan, M.L., Imran, F.A., Kosasih, E.A., Nugroho, Y.S., 2017. Investigation of Smoldering Combustion Propagation of Dried Peat. AIP Conference Proceedings, Volume 1826(1), pp. 020017

Perdana, L., Ratnasari, N., Ramadhan, M., Palamba, P., Nugroho, Y.S., 2018. Hydrophilic and Hydrophobic Characteristics of Dry Peat. IOP Conference Series: Earth and Environmental Science, Volume 105

Piman, T., Pawattana, C., Vansarochana, A., Aekakkararungroj, A., Hormwichian, R., 2016. Analysis of Historical Changes in Rainfall in Huai Luang Watershed, Thailand. International Journal of Technology, Volume 7(7), pp. 1155-1162

Prat-Guitart, N., Rein, G., Hadden, R.M., Belcher, C.M., Yearsley, J.M., 2016. Propagation Probability and Spread Rates of Self-sustained Smouldering Fires under Controlled Moisture Content and Bulk Density Conditions. International Journal of Wildland Fire, Volume 25(4), pp. 456-465

Ramadhan, M.L., Palamba, P., Imran, F.A., Kosasih, E.A., Nugroho, Y.S., 2017. Experimental Study of the Effect of Water Spray on the Spread of Smoldering in Indonesian Peat Fires. Fire Safety Journal, Volume 91, pp. 671-679

Rein, G., Garcia, J., Simeoni, A., Tihay, V., Ferrat, L., 2008. Smouldering Natural Fires: Comparison of Burning Dynamics in Boreal Peat and Mediterranean Humus. WIT Transactions on Ecology and the Environment, Volume 119, pp. 183-192

Ritung, S., Wahyunto, N.K., 2012. Karakteristik dan Sebaran Lahan Gambut di Sumatera, Kalimantan dan Papua (Characteristics and Distribution of Peatlands in Sumatra, Kalimantan and Papua). Pengelolaan Lahan Gambut Berkelanjutan (Sustainable Management of Peatlands), Balai Besar Litbang SDLP, Bogor, Indonesia 
Saleh, M., Muharram, Y., Nugroho, Y.S., 2017. Modeling of the Crossing Point Temperature Phenomenon in the Low-temperature Oxidation of Coal. International Journal of Technology, Volume 8(1), pp. 104-113

Valat, B., Jouany, C., Riviere, L., 1991. Characterization of the Wetting Properties of Air Dried Peats and Composts [Surface Tension, Water Retention Capacity]. Soil Science, Volume 152(2), pp. 100-107 